\title{
Impact of Fission Products Impurity on the Plutonium Content of Metal- and Oxide- Fuels in Sodium Cooled Fast Reactors
}

Hikaru Hiruta

Gilles Youinou

September 2013

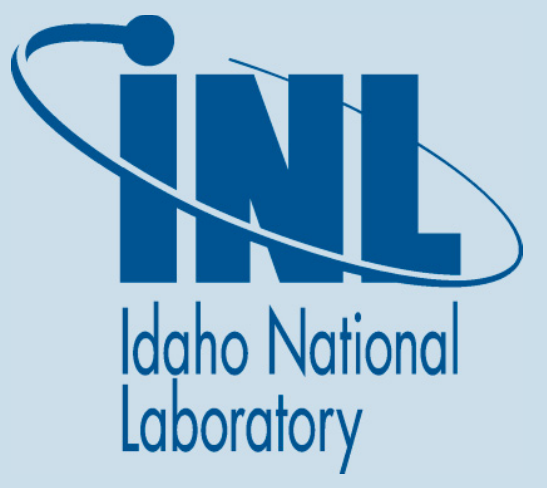

The INL is a U.S. Department of Energy National Laboratory operated by Battelle Energy Alliance 


\section{DISCLAIMER}

This information was prepared as an account of work sponsored by an agency of the U.S. Government. Neither the U.S. Government nor any agency thereof, nor any of their employees, makes any warranty, expressed or implied, or assumes any legal liability or responsibility for the accuracy, completeness, or usefulness, of any information, apparatus, product, or process disclosed, or represents that its use would not infringe privately owned rights. References herein to any specific commercial product, process, or service by trade name, trade mark, manufacturer, or otherwise, does not necessarily constitute or imply its endorsement, recommendation, or favoring by the U.S. Government or any agency thereof. The views and opinions of authors expressed herein do not necessarily state or reflect those of the U.S. Government or any agency thereof. 


\section{Impact of Fission Products Impurity on the Plutonium Content of Metal- and Oxide- Fuels in Sodium Cooled Fast Reactors}

Hikaru Hiruta

Gilles Youinou

September 2013

Idaho National Laboratory

Reactor Physics Analysis \& Design Department

Idaho Falls, Idaho 83415

Prepared for the

U.S. Department of Energy

Office of Nuclear Energy

Under U.S. Department of Energy-Idaho Operations Office

Contract DE-AC07-05ID14517 



\section{CONTENTS}

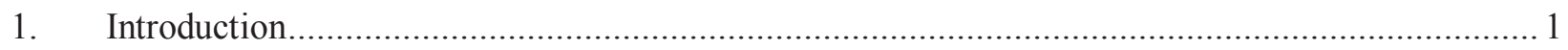

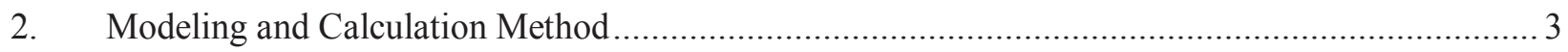

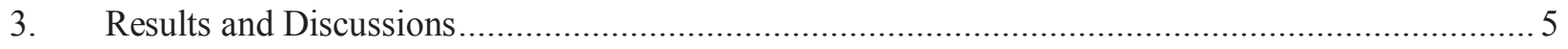

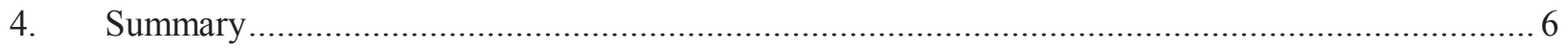

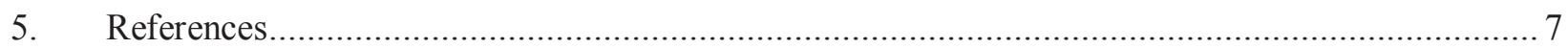

\section{FIGURES}

Figure 1. TRITON quarter-assembly models of metal- and oxide-fuel assemblies. ............................... 4

Figure 2. Pu enrichments as a function of FP losses for the metal-fuel assembly. ............................... 5

Figure 3. Pu enrichments as a function of FP losses for the oxide-fuel assembly. ................................ 6

\section{TABLES}

Table 1. Pu and FP present in the reference $51 \mathrm{GWd}$ /TIHM UOX SNF (10-year cooling time) ............... 1

Table 2. Composition of the $P u^{F P}$ mixture as a function of the FP losses during the reprocessing of UOX SNF......

Table 3. Assembly dimensions and other physical data for SFR assembly modeling.............................. 3

Table 4. Pu enrichments as a function of FP losses for the metal-fuel assembly ...................................5

Table 5. Pu enrichments as a function of FP losses for the oxide-fuel assembly................................. 6 



\section{FUEL CYCLE OPTIONS CAMPAIGN IMPACT OF FISSION PRODUCTS IMPURITY ON THE PLUTONIUM CONTENT OF METAL- AND OXIDE- FUEL IN SODIUM COOLED FAST REACTORS}

\section{Introduction}

This short report presents the neutronic analysis to evaluate the impact of fission product impurity on the Pu content of Sodium-cooled Fast Reactor (SFR) metal- and oxide- fuel fabrication. The similar work has been previously done for PWR MOX fuel [1]. The analysis will be performed based on the assumption that the separation of the fission products (FP) during the reprocessing of UOX spent nuclear fuel assemblies is not perfect and that, consequently, a certain amount of FP goes into the Pu stream used to fabricate SFR fuels. Only non-gaseous FPs have been considered (see the list of 176 isotopes considered in the calculations in Appendix 1 of Reference 1). Throughout of this report, we define the mixture of Pu and FPs as $P u^{F P}$.

The main objective of this analysis is to quantify the increase of the Pu content of SFR fuels necessary to maintain the same average burnup at discharge independently of the amount of FP in the $\mathrm{Pu}$ stream, i.e. independently of the $P u^{F P}$ composition. The FP losses are considered element-independent, i.e., for example, $1 \%$ of FP losses mean that $1 \%$ of all non-gaseous FP leak into the Pu stream.

The amount of $\mathrm{Pu}$ and FP present in the reference $51 \mathrm{GWd}$ /TIHM UOX SNF (4.3\% U-235) after 10 years of cooling time is given in Table 1 below. It shows that 1 ton of UOX SNF contains $11.33 \mathrm{~kg} \mathrm{of} \mathrm{Pu}$ and $44.05 \mathrm{~kg}$ of non-gaseous FP, hence, for example, if the FP losses are equal to $1 \mathrm{wt} \%$, the $P u^{F P}$ mixture contains $11.33 \mathrm{~kg}$ of $\mathrm{Pu}$ and $0.4405 \mathrm{~kg}$ of non-gaseous $\mathrm{FP}$, or put in differently, $P u^{F P}-1 \%=96.26$ $\mathrm{wt} \% \mathrm{Pu}+3.74 \mathrm{wt} \% \mathrm{FP}$. The compositions of the $P u^{F P}$ mixture as a function of the FP losses during the reprocessing of UOX SNF are presented in Table 2. After the $\mathrm{Pu}$ (or $P u^{F P}$ ) has been separated, an additional 1-year decay period is also taken into account before the MOX fuel is actually loaded in the reactor in order to allow for transportation and fuel fabrication. During this 1 -year about $5 \%$ of the ${ }^{241} \mathrm{Pu}$ decays on ${ }^{241} \mathrm{Am}$.

The rest of this report is organized as followings. Section 2 explains in detail the computational method and modeling used for the analysis. Section 3 talks about results (i.e., Pu enrichment as a function of FP loss) of calculations. Finally Section 4 summarizes the report.

Table 1. Pu and FP present in the reference $51 \mathrm{GWd} / \mathrm{TIHM}$ UOX SNF (10-year cooling time)

\begin{tabular}{|c|c|}
\hline Isotope & $\mathrm{kg} / \mathrm{TIHM}$ \\
\hline $\mathrm{Pu} 238$ & 0.295 \\
\hline $\mathrm{Pu} 239$ & 6.153 \\
\hline $\mathrm{Pu} 240$ & 2.930 \\
\hline $\mathrm{Pu} 241$ & 1.086 \\
\hline $\mathrm{Pu} 242$ & 0.864 \\
\hline Total $\mathrm{Pu}$ & 11.33 \\
\hline ToTal FP & 52.64 \\
\hline Total FP (non-gas) & 44.05 \\
\hline RatioFP/Pu & 4.646 \\
\hline Ratio FP $_{\text {non-gas }} / \mathrm{Pu}$ & 3.888 \\
\hline
\end{tabular}


Table 2. Composition of the $P u^{F P}$ mixture as a function of the FP losses during the reprocessing of UOX SNF

\begin{tabular}{|c|c|c|}
\hline FP losses [wt\%] & FP in the $P u^{F P}$ mixture [wt\%] & $\mathrm{Pu}$ in the $P u^{F P}$ mixture [wt\%] \\
\hline 0.25 & 0.96 & 99.04 \\
\hline 0.50 & 1.91 & 98.09 \\
\hline 0.75 & 2.83 & 97.17 \\
\hline 1.00 & 3.74 & 96.26 \\
\hline 2.00 & 7.22 & 92.78 \\
\hline 3.00 & 10.45 & 89.55 \\
\hline 4.00 & 13.46 & 86.54 \\
\hline 5.00 & 16.28 & 83.72 \\
\hline
\end{tabular}




\section{Modeling and Calculation Method}

SCALE6.1.2 [2] code system has been selected to perform all calculations because of its capability to handle several types of reactor physics and criticality safety simulations including lattice physics calculations. NEWT, which is the 2D discrete ordinates solver in non-orthogonal geometries, has a capability to model heterogeneous assembly geometry by closely approximating curved geometries. TRITON module, which effectively couples NEWT with ORIGEN depletion module, performs burnup calculations together with the automated cross section processing such as resonance self-shielding calculations by BONAMI (unresolved range) and CENTRM (resolved range) at each depletion subinterval. The 238-group ENDF/B-VII.1 library has been used for these calculations.

The assembly dimensions and other physical data for the fuel are determined based on S-PRISM and ABR designs in References 3 and 4. These data are presented in Table 3. Figure 1 shows the plot of modeled geometries for both assemblies. The color of each fuel-pin cell represents the burnup zoning. Instead of modeling the gap between fuel pellet surface and clad inner surface, the fuel is smeared into the gap region, and its density is multiplied by the volume ratio. Only a quarter of each assembly is modeled by applying the reflective boundary condition at each orthogonal surface (top, bottom, and left) and white boundary condition at the non-orthogonal surface (right). The unstructured version of Coarse-Mesh Finite-Difference (CMFD) method is applied in order to accelerate the convergence of inner iterations. The thermal iteration is turned off since negligible contribution from thermal energy groups is expected in both fast reactor assemblies. The product quadrature set is assigned to have six directions per quadrant ( 2 polar $\times 3$ azimuthal angles).

Table 3. Assembly dimensions and other physical data for SFR assembly modeling.

\begin{tabular}{|c|c|c|}
\hline & Metal-Fueled Assembly & Oxide-Fueled Assembly \\
\hline Number of Fuel Pins & 271 & 217 \\
\hline Fuel-Pin Inner Diameter [cm] & 0.6322 & 0.724 \\
\hline Fuel-Pin Outer Diameter [cm] & 0.744 & 0.851 \\
\hline Fuel-Pin Pitch [cm] & 0.90687 & 1.01356 \\
\hline P/D & 1.21891 & 1.19102 \\
\hline Assembly Pitch [cm] & 16.1417 & 16.1417 \\
\hline Duct Gap [cm] & 0.4318 & 0.4318 \\
\hline Duct Wall Thickness [cm] & 0.3937 & 0.3937 \\
\hline Fuel Density [g/cm $\left.{ }^{3}\right]$ & 15.05 & 11.05 \\
\hline Smeared Fuel Density [g/cm $\left.{ }^{3}\right]$ & 11.30 & 10.50 \\
\hline Clad (HT9) Density [g/cm $\left.{ }^{3}\right]$ & 7.894 & 7.894 \\
\hline Coolant (Na) Density [g/cm $\left.{ }^{3}\right]$ & 0.8136 & 0.8136 \\
\hline Average Discharge Burnup [GWd/t] & 73 & 102.6 \\
\hline Specific Power [W/g] & 42.5 & 30.4 \\
\hline EFPD [days] & 1717.6 & 3375 \\
\hline Fuel Temperature [ $\left.{ }^{\circ} \mathrm{K}\right]$ & 885.33 & 1196 \\
\hline Clad (HT9) Temperature [ $\left.{ }^{\circ} \mathrm{K}\right]$ & 793.82 & 795.3 \\
\hline Coolant Temperature [ $\left.{ }^{\circ} \mathrm{K}\right]$ & 793.82 & 795.3 \\
\hline Reference Pu Enrichment [wt\%] & 13.4 & 17.2 \\
\hline
\end{tabular}




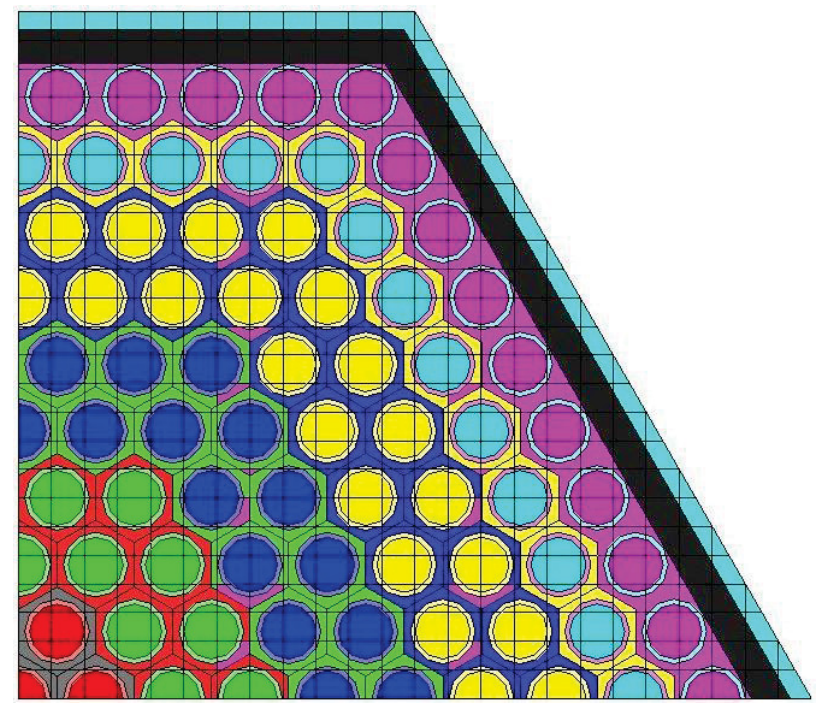

(a) Metal-Fuel Assembly Model

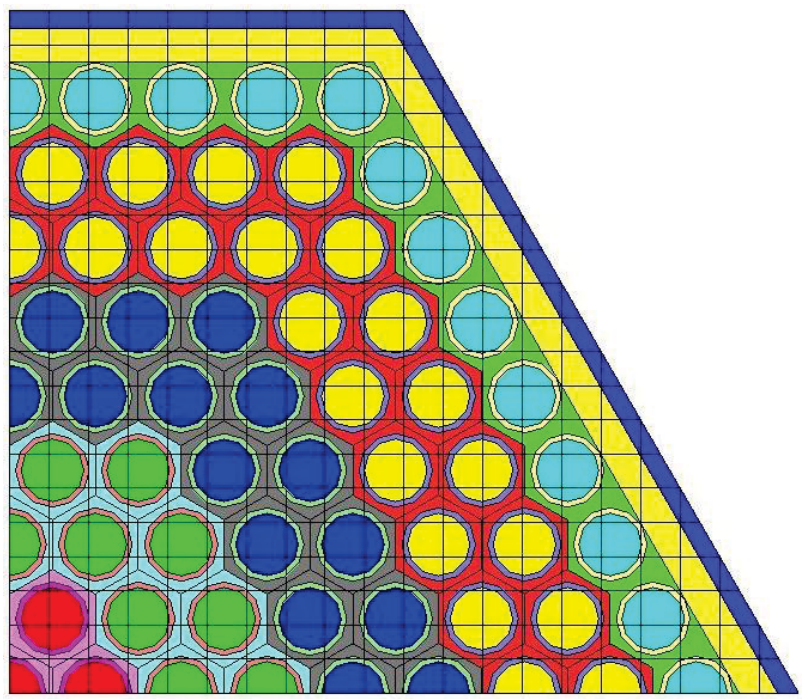

(b) Oxide-Fuel Assembly Model

Figure 1. TRITON quarter-assembly models of metal- and oxide-fuel assemblies.

All models take into account 1 year of aging after the fuel fabrication. The 3-batch scheme is assumed for both assemblies. This will give the average end-of-cycle (EOC) burnup of $48.7 \mathrm{GWd} / \mathrm{t}$ for metal-fuel and $68.4 \mathrm{GWd} / \mathrm{t}$ for oxide-fuel assemblies. Calculations based on the reference $\mathrm{Pu}$ enrichment in Table 1 without any fission-products show that $k_{\infty}$ at average EOC burnup is equal to 1.2020 for metal-fuel and 1.1617 for oxide fuel assemblies. These are the conditions necessary to hold at every time adding fission products into fuel compositions. Therefore, $P u^{F P}(\mathrm{Pu}+\mathrm{FP})$ enrichments are determined by iterative approach in order to obtain the same $k_{\infty}$ at the average EOC burnup. 


\section{Results and Discussions}

Calculations have been performed for both metal-fuel and oxide-fuel assemblies shown in Table 3 and Figure 1. The $P u^{F P}$ enrichments are determined by adjusting them until $k_{\infty}$ at the average EOC burnup becomes equal to that of the reference core. Note that there has been a bias observed in our results exhibiting a jump in $P u^{F P}$ enrichment between $0 \mathrm{wt} \%$ and negligibly small amount (say a $10000^{\text {th }}$ of a percentage) of FP losses followed by linear increase of the enrichment, possibly caused by the introduction of a large number of FPs (i.e., 176 FPs). Therefore, this bias has been subtracted from calculated $P u^{F P}$ enrichments $(0.08 \mathrm{wt} \%$ for the metal-fuel and $0.167 \mathrm{wt} \%$ for the oxide fuel assemblies), which is the same treatment made in Reference 1.

Table 4 and Figure 2 show $P u^{F P}$ and Pu content in the metal-fuel assembly necessary to maintain the same average burnup at discharge of $73 \mathrm{GWd} / \mathrm{TIHM}$ independently of the amount of the FP losses. The same set of results for the oxide-fuel assembly, which has discharge of $102.6 \mathrm{GWd} / \mathrm{TIHM}$, is presented in Table 5 and Figure 3. By analyzing the slope of each plot, it can be seen that the mass of Pu increases approximately $0.85 \%$ per percent of FP losses for the metal-fuel assembly and $1.1 \%$ per percent of FP losses for the oxide-fuel assembly. (Note that the Pu content increase in PWR MOX fuel is $\sim 3.5 \%$ per percent of FP losses [1]).

Table 4. Pu enrichments as a function of FP losses for the metal-fuel assembly.

\begin{tabular}{|c|c|c|}
\hline FP losses [wt \%] & $P u^{F P}$ enrichment [wt \%] & Pu enrichment [wt\%] \\
\hline 0.00 & 13.400 & 13.400 \\
\hline 0.25 & 13.564 & 13.433 \\
\hline 0.50 & 13.722 & 13.460 \\
\hline 0.75 & 13.883 & 13.489 \\
\hline 1.00 & 14.042 & 13.516 \\
\hline 2.00 & 14.692 & 13.632 \\
\hline 3.00 & 15.347 & 13.744 \\
\hline 4.00 & 16.017 & 13.860 \\
\hline 5.00 & 16.691 & 13.974 \\
\hline
\end{tabular}

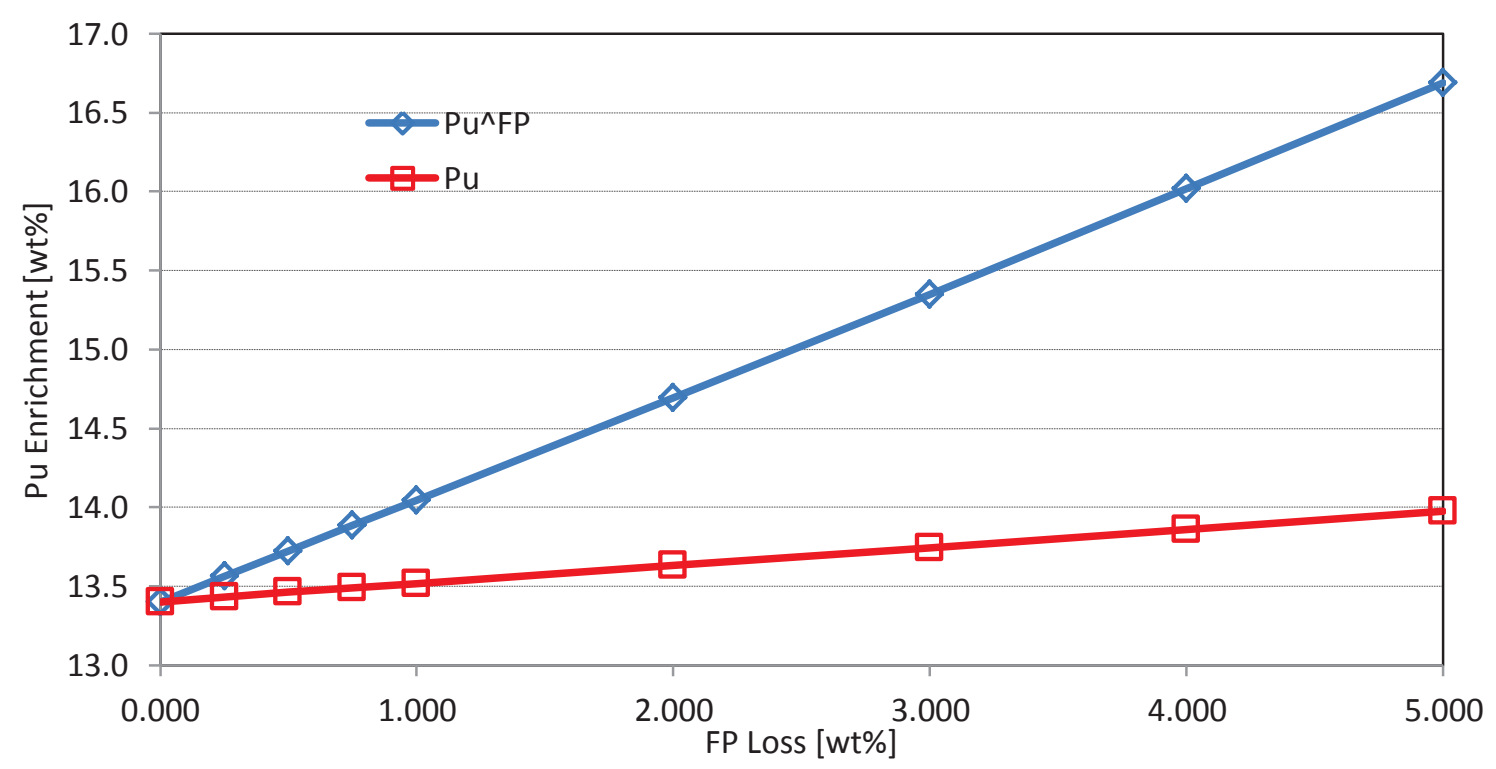

Figure 2. Pu enrichments as a function of FP losses for the metal-fuel assembly. 
Table 5. Pu enrichments as a function of FP losses for the oxide-fuel assembly.

\begin{tabular}{|c|c|c|}
\hline FP losses [wt\%] & $P u^{F P}$ enrichment [wt\%] & Pu enrichment [wt\%] \\
\hline 0.00 & 17.200 & 17.200 \\
\hline 0.25 & 17.416 & 17.249 \\
\hline 0.50 & 17.633 & 17.297 \\
\hline 0.75 & 17.851 & 17.345 \\
\hline 1.00 & 18.069 & 17.393 \\
\hline 2.00 & 18.949 & 17.582 \\
\hline 3.00 & 19.841 & 17.768 \\
\hline 4.00 & 20.748 & 17.955 \\
\hline 5.00 & 21.668 & 18.141 \\
\hline
\end{tabular}

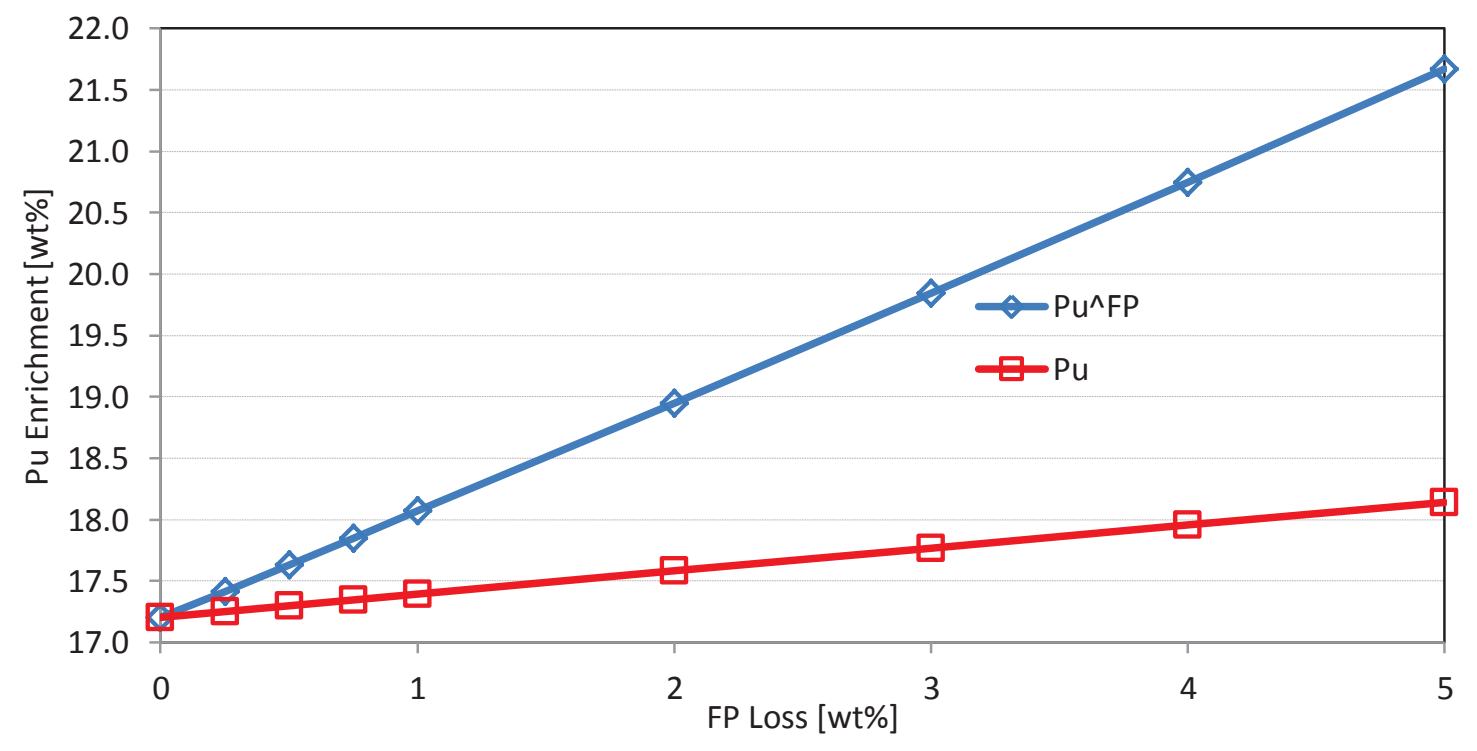

Figure 3. Pu enrichments as a function of FP losses for the oxide-fuel assembly.

\section{Summary}

This short report presented the neutronic analysis to evaluate the impact of fission product impurity on the Pu content of SFR fuel fabrication. The analysis was performed based on the assumption that the separation of the fission products (FP) during the reprocessing of UOX spent nuclear fuel assemblies is not perfect and that, consequently, a certain amount of FP goes into the Pu stream used to SFR fuels. TRITON module in SCALE6.1.2 was used for this analysis.

The main objective of this analysis was to quantify the increase of the Pu content of SFR fuels necessary to maintain the same average burnup at discharge $(73 \mathrm{GWd} / \mathrm{TIHM}$ for metal-fuel assembly and 102.6 GWd/TIHM for oxide-fuel assembly) independently of the amount of FP in the Pu stream, i.e. independently of the $P u^{F P}$ composition. The FP losses were considered element-independent, i.e., for example, $1 \%$ of FP losses mean that $1 \%$ of all non-gaseous FP leak into the Pu stream.

Calculations showed that the Pu content of SFR fuels increased approximately $0.85 \%$ per percent of FP losses for the metal-fuel assembly and $1.1 \%$ per percent of FP losses for the oxide-fuel assembly. These were significantly less than the Pu content increase in PWR MOX fuel $(\sim 3.5 \%$ per percent of FP losses). 


\section{References}

1. A. Alfonsi and G. Youinou, "Impact of Fission Products Impurity on the Plutonium Content in PWR MOX Fuels," INL/EXT-12-26114 (2012).

2. Scale: A Comprehensive Modeling and Simulation Suite for Nuclear Safety Analysis and Design, ORNL/TM-2005/39, Version 6.1, June 2011. Available from Radiation Safety Information Computational Center at Oak Ridge National Laboratory as CCC-785.

3. A. E. Dubberley, K. Yoshida, Ce. E. Boardman, and T. Wu, "SuperPRISM Oxide and Metal Fuel Core Designs," Proc. $8^{\text {th }}$ Int. Conf. Nucl. Eng. (ICONE 8), April 2-6, 2000, Baltimore, MD (2000).

4. E. A. Hoffman, W. S. Yang, and R. N. Hill, "Preliminary Core Design Studies for the Advanced Burner Reactor over a Wide Range of Conversion Ratios," ANL-AFCI-177 (2006). 